\title{
Modification of secondary products of processing triticale into starch with a new strain of the fungus Geotrichium candidum
}

\author{
$V V$ Kolpakova $^{1, *}, R V$ Ulanova $^{2}$, and $D S$ Kulikov $^{1}$ \\ ${ }^{1}$ All-Russian Research Institute for Starch Products - Branch of V.M. Gorbatov Federal Research \\ Center for Food Systems of Russian Academy of Sciences, 11, Nekrasova St., Kraskovo, Moscow \\ region, 140051, Russian Federation \\ ${ }^{2}$ S.N. Vinogradsky Institute of Microbiology, Federal Research Center "Fundamental Foundations of \\ Biotechnology", Russian Academy of Sciences, 7, 60th anniversary of October Ave., Moscow, \\ 107143, Russian Federation
}

\begin{abstract}
The aim of this work was to study the possibility of using a new strain of the fungus Geotrichum candidum for the bioconversion of serum remaining after the isolation of starch and proteins from triticale grain. The fungus strain Geotrichum candidum 977 was isolated from the steep waters of triticale grains formed during the production of starch and identified on the basis of analysis of the sequence of ribosomal genes. The strain was characterized by large cells efficient separation of biomass from the culture liquid and high growth rate. On protein-free whey, which remains after isolating proteins from steeping waters the fungus assimilated glucose, maltotriose, fructose and did not assimilate maltose. At a $\mathrm{pH}$ of 5.0 the growth of the fungus was not observed at a $\mathrm{pH}$ of 5.5 to 6.5 it was weak at a $\mathrm{pH}$ of 7.5 to 8.5 , the productivity of the fungus increased 1.8 times and amounted to $3.00-3,15 \mathrm{~g} / 100 \mathrm{~cm}^{3}$. During growth the strain alkalized the medium from $\mathrm{pH} 5.5$ to $\mathrm{pH} 8.5$. The microbial-plant concentrate contained $33.3 \pm 2.1 \%$ protein and 19 amino acids with a predominance of alanine, aspartic, glutamic acids, lysine, threonine and leucine. The score of essential amino acids exceeded $100 \%$ with the exception of sulfurcontaining ones (64-72\%). Thus, the possibility of using a new strain of the fungus G. Candidum 977 for the utilization of wastewater generated during the production of starch and proteins from triticale grains has been shown to obtain fodder protein concentrates.
\end{abstract}

\section{Introduction}

For the food and processing industry, it is urgent to eliminate the negative impact on the biosphere of liquid processed products of raw materials which without treatment merge into the sewers or agricultural fields. In the production of starch from cereals soaking waters are formed that are not completely utilized. Known technologies for the treatment of liquid

\footnotetext{
* Corresponding author: val-kolpakova@rambler.ru
} 
waste include mechanical (filtration, sedimentation, flotation), chemical-physical (coagulation, neutralization, etc.) or biological methods (aeroteki, biofilters) [1-4]. These methods make it possible to achieve waste neutralization, but with them a part of useful organic and mineral components of the raw material is lost. Technologies for using biological agents are more effective while micromycetes are used in the process of recycling secondary products to produce protein biomass for food or feed purposes most often the genera Trichoderma and Aspergillus. Thus, fodder biomass with the monocultures Trich. Longibrachiatum, Asp. Terreus, as well as with the association of Asp. Sp. And Trich. Viride biomass cultures with a protein mass fraction $19.0-43.7 \%$ of DS were obtained from waste from the processing of sorghum grain, rice and sugar production [5-7]. The product with a mass fraction of protein of $19.8-36.0 \%$ was also obtained by biotransformation of wastewater generated from wine production with cultures Trich. Viride, Asp. Niger and Asp. Oryzae [8]. In the production of fodder biomass of Candida utilis yeast, potato wastewater with the addition of $5 \%$ glycerol was successfully used, the efficiency of protein biosynthesis was $12.2 \mathrm{~g} / 1$ [9]. In deep cultivation of Candida utilis on fruit waste extract with the addition of soluble starch, nitrogen, ammonium nitrate as a carbon source, a fodder yeast biomass containing 49\% protein was obtained [10]. The yeast biomass Yarrowia lipolytica obtained on cheap by-products and successfully tested for feeding animals in addition to protein (up to 60\%) also included polyunsaturated fatty acids [11]. Waste water fermentation from starch production with Asp. Oryzae allowed other authors to obtain biomass containing 38-45\% protein for feed in livestock. Fodder biomass with Asp. Terreus uni MAPAA-1 with a yield of $1.68 \mathrm{~g} / \mathrm{dm}^{3}$ of protein was synthesized on waste from palm oil production using $15 \%$ seed [12].

In the food industry in particular in the production of cheese micromycetes of the genus Geotrichum [13] are used for ripening the formation of taste and aroma. The ability of these fungi to synthesize physiologically active compounds is also used in other areas of biotechnology [14-15]. Thus, work was done to study the possibility of producing protein with G. candidum MIUG and G. Candidum LPMOs strains on waste cellulose-containing raw materials produced in paper production [16-17] and on alcohol bard to produce a foaming additive with $G$. candidum C3-106 strains (ARCIM F-220) and G. candidum B (ARCIM F-267) [18]. Another strain of G. candidum AN-Z4 culture isolated from anthropogenically contaminated territory caused deep destruction of trinitrotoluene under conditions of intensive aeration and was recommended for disinfection of contaminated territories [19]. Thus, it is advisable to investigate the fungi of the genus Geotrichum to determine the possibility of processing secondary products resulting from the production of starch (extracts, soaking waters) with a modification of their chemical composition to avoid harming the environment. We have already shown that bioconversion of secondary products of triticale grain processing should be carried out with the yeast Saccharomyces cerevisiae [20] and the fungus Pleurotus [21].

The aim of this work was to study the process of modifying the secondary product of the processing of triticale grains into starch (serum) by bioconversion with a new strain of the Geotrichum fungus to obtain a feed microbial-vegetable concentrate (MVC).

\section{Materials and methods}

As the object of modification we used the serum remaining after the removal of proteins from the soaking waters of triticale grains released upon receipt of starch [20]. The grain was soaked for 24 hours at a temperature of $49 \pm 1{ }^{\circ} \mathrm{C}$, crushed and a suspension was obtained which was held for 4 hours at $48 \pm 1{ }^{\circ} \mathrm{C}$ to activate the enzymes. The mixture was crushed, centrifuged and a liquid fraction was obtained, which was treated with cytolytic, hemicellulase and amylase enzymes. The suspension was centrifuged, a solution was 
obtained from which a protein with a mass fraction in the sediment of $71 \pm 1.2 \%$ was deposited at the isoelectric point $(\mathrm{pH}=4.2 \pm 0.2)$. The liquid part (serum) was used as a growth medium for $G$. candidum 977. The inoculum was obtained by reseeding the museum culture from a test tube with wort agar into a test tube with agarized serum, then after 24 hours of cultivation the culture was transferred to $300 \mathrm{~cm}^{3}$ flasks with $50 \mathrm{~cm}^{3}$ serum and grown on a shaker at $150 \mathrm{~min}^{-1}$ and $27{ }^{\circ} \mathrm{C}$. The biomass with the culture fluid and separately from the fluid was freeze-dried.

Mass fraction of protein in MVC was determined based on the amino acid composition. Amino acid composition was studied using a Hitachi model L-8800 liquid chromatograph (Japan) in the standard mode of analysis of protein hydrolysates. The amino acid rate was calculated taking into account the FAO / WHO reference scale (2011). To determine carbohydrates 1-2 $\mathrm{mg}$ of the sample was dissolved in $1 \mathrm{~cm}^{3}$ of pyridine, the solution was transferred to the reaction vial and $100 \mu \mathrm{m} / \mathrm{dm}^{3}$ of BSTFA + TMCS solution (99:1) (Supelco) was added. Vials with samples were placed in a thermostat at $70{ }^{\circ} \mathrm{C}$ for $1 \mathrm{~h}$. Silyl derivatives were studied on a Shimadzu GCMS 2010 gas chromatograph with a GCMS-QP 2010 mass spectrometric detector. Peaks were identified by the NIST 11 mass spectra library.

The identification of the strain was carried out on the basis of the analysis of the sequence of ribosomal genes in stages: sieving the culture to individual colonies; obtaining biomass for analysis of 18S RNA; DNA isolation (Genomic DNA Purification Kit) and strain identification by the sequence of $18 \mathrm{~S}$ rDNA. Consistent primers were used to generate the sequence of the gene encoding 18S rRNA: NS1-gtagtcatatgcttgtctc, NS4cttccgtcaattcctttaag, to generate the sequence of the gene encoding 5,8S rRNA - internal transcribed spacers ITS1 and ITS2:ITS1 - TCCGTAGGTGAACCTGCG, ITS4 TCCTCCGCTTATTGATATGCT [22]. For domain amplification, conservative primers D1/D2 of the 26S rRNA gene were used: NL-1 GCATATCAATAAGCGGAGGAAAG, NL-4 GGTCCGTGTTTCAAGACGG. Sequencing of 18S rRNA and 5.8S rRNA genes was performed on an AE 3000 automated sequencer with the BLAST computer program [http://www.ncbi.nlm.nih.gov/blast]. Identification was carried out using primers specific for Fusariumequiseti: FEF15'-CATACCTATACGTTGCCTCG-3'; FER1 5'TTACCAGTAACGAGGTGTATG-3'. Electrophoresis of the samples was carried out on a $1.0 \%$ agarose gel at a voltage of $5 \mathrm{~W} / \mathrm{cm}$. A similarity analysis of the nucleotide sequence of the gene encoding the $18 \mathrm{~S}$ rDNA strain was performed using the BLAST server [http://www.ncbi.nlm.nih.gov/blast].

\section{Results and discussion}

In the process of soaking grain in the production of starch, a fungal strain was isolated that is able to adapt to various food sources, rapid growth and active accumulation of biomass in the key waters of this production. When analyzing the sequence of ribosomal genes, primary screening using the GenBank database showed that the strain studied belonged to systematic groups: Eukaryota; Fungi; Dikarya; Ascomycota; Saccharomycotina; Saccharomycetes; Saccharomycetales; Dipodascaceae; Geotrichum. The criterion for classifying a microorganism to a particular species is considered to be at least $97 \%$ homology [2]. To establish the phylogenetic kinship of closely related species, the method of comparing nucleotide sequences encoding the D1/D2 domain of the 26S rRNA gene was additionally used. The strains used for analysis and the level of similarity of the sequence encoding the D1/D2 domain of the 26S rRNA gene of the studied strain are shown in table 1 . 
Table 1. Species identification of the fungus based on a sequence analysis of the $26 \mathrm{~S}$ rRNA gene.

\begin{tabular}{|c|c|c|c|}
\hline Description & $\begin{array}{l}\text { Query } \\
\text { cover, } \%\end{array}$ & $\begin{array}{c}\text { Identification, } \\
\%\end{array}$ & Accession \\
\hline $\begin{array}{l}\text { Galactomyces candidum strain Y11 26S } \\
\text { ribosomal RNA gene, partial sequence }\end{array}$ & 98 & 99 & KM391959.1 \\
\hline $\begin{array}{l}\text { Galactomyces candidum isolate TR 13.c 26S } \\
\text { ribosomal RNA gene, partial sequence }\end{array}$ & 97 & 99 & KP017413.1 \\
\hline $\begin{array}{l}\text { Geotrichum candidum strain TOM_YEAST small } \\
\text { subunit ribosomal RNA gene, partial sequence; } \\
\text { internal transcribed spacer } 1,5.8 \mathrm{~S} \text { ribosomal } \\
\text { RNA gene, and internal transcribed spacer } 2 \text {, } \\
\text { complete sequence; and large subunit ribosomal } \\
\text { RNA gene, partial sequence }\end{array}$ & 97 & 99 & KF112070.1 \\
\hline $\begin{array}{c}\text { Galactomyces geotrichum strain LMA-70 18S } \\
\text { ribosomal RNA gene, partial sequence; internal } \\
\text { transcribed spacer 1, 5.8S ribosomal RNA gene, } \\
\text { and internal transcribed spacer 2, complete } \\
\text { sequence; and 26S ribosomal RNA gene, partial } \\
\text { sequence }\end{array}$ & 97 & 99 & JQ668740.1 \\
\hline $\begin{array}{c}\text { Galactomyces geotrichum strain LMA-21 18S } \\
\text { ribosomal RNA gene, partial sequence; internal } \\
\text { transcribed spacer 1, 5.8S ribosomal RNA gene, } \\
\text { and internal transcribed spacer 2, complete } \\
\text { sequence; and 26S ribosomal RNA gene, partial } \\
\text { sequence }\end{array}$ & 97 & 99 & JQ668739.1 \\
\hline $\begin{array}{l}\text { Galactomyces geotrichum strain GG002 26S } \\
\text { ribosomal RNA gene, partial sequence }\end{array}$ & 97 & 99 & JQ713185.1 \\
\hline $\begin{array}{l}\text { Galactomyces candidum strain CBS 607.85 26S } \\
\text { ribosomal RNA gene, partial sequence }\end{array}$ & 97 & 99 & JN974268.1 \\
\hline $\begin{array}{l}\text { Galactomyces candidum strain CBS 606.85 26S } \\
\text { ribosomal RNA gene, partial sequence }\end{array}$ & 97 & 99 & JN974267.1 \\
\hline $\begin{array}{l}\text { Galactomyces geotrichum strain SD3-a 26S } \\
\text { ribosomal RNA gene, partial sequence }\end{array}$ & 97 & 99 & HM754448.1 \\
\hline $\begin{array}{l}\text { Galactomyces geotrichum strain SD2-d 26S } \\
\text { ribosomal RNA gene, partial sequence }\end{array}$ & 97 & 99 & HM754447.1 \\
\hline $\begin{array}{l}\text { Galactomyces geotrichum strain NX5 26S } \\
\text { ribosomal RNA gene, partial sequence }\end{array}$ & 97 & 99 & HM754438.1 \\
\hline $\begin{array}{l}\text { Galactomyces geotrichum strain ATCC } 34614 \\
18 \mathrm{~S} \text { ribosomal RNA gene, partial sequence; } \\
\text { internal transcribed spacer 1, 5.8S ribosomal } \\
\text { RNA gene, and internal transcribed spacer } 2 \text {, } \\
\text { complete sequence; and 28S ribosomal RNA } \\
\text { gene, partial sequence }\end{array}$ & 97 & 99 & GQ458034.1 \\
\hline $\begin{array}{c}\text { Geotrichum sp. 5.3-1 26S ribosomal RNA gene, } \\
\text { partial sequence }\end{array}$ & 97 & 99 & FJ473451.1 \\
\hline $\begin{array}{c}\text { Galactomycescandidum 26S ribosomal RNA } \\
\text { gene, partial sequence }\end{array}$ & 97 & 99 & KF015740.1 \\
\hline $\begin{array}{l}\text { Geotrichum sp. BUF9 gene for 26S ribosomal } \\
\text { RNA, partial sequence, strain: BUF9 }\end{array}$ & 97 & 99 & AB741075.1 \\
\hline $\begin{array}{l}\text { Geotrichum sp. BUF7 gene for 26S ribosomal } \\
\text { RNA, partial sequence, strain: BUF7 }\end{array}$ & 97 & 99 & AB741073.1 \\
\hline $\begin{array}{c}\text { Geotrichum silvicola gene for 26S rRNA, partial } \\
\text { sequence, strain: EM } 17\end{array}$ & 97 & 99 & AB281297.1 \\
\hline $\begin{array}{l}\text { Galactomyces geotrichum strain GS6A 26S } \\
\text { ribosomal RNA gene, partial sequence }\end{array}$ & 97 & 99 & HM754437.1 \\
\hline
\end{tabular}




\begin{tabular}{|c|c|c|c|}
\hline $\begin{array}{l}\text { Galactomycesgeotrichum strain Q55-2 26S } \\
\text { ribosomal RNA gene, partial sequence }\end{array}$ & 97 & 99 & HM754444.1 \\
\hline $\begin{array}{l}\text { Galactomycesgeotrichum strain Q1-2 26S } \\
\text { ribosomal RNA gene, partial sequence }\end{array}$ & 97 & 99 & HM754439.1 \\
\hline $\begin{array}{l}\text { Galactomyces geotrichum strain Q30-1 26S } \\
\text { ribosomal RNA gene, partial sequence }\end{array}$ & 97 & 99 & HM754440.1 \\
\hline $\begin{array}{l}\text { Galactomyces candidum strain } 13-126 \mathrm{~S} \\
\text { ribosomal RNA gene, partial sequence }\end{array}$ & 96 & 99 & KC967683.1 \\
\hline $\begin{array}{l}\text { Galactomycesgeotrichum strain SD1-a 26S } \\
\text { ribosomal RNA gene, partial sequence }\end{array}$ & 97 & 99 & HM754445.1 \\
\hline $\begin{array}{l}\text { Uncultured compost fungus clone 3F09 26S } \\
\text { ribosomal RNA gene, partial sequence }\end{array}$ & 97 & 99 & DQ365444.1 \\
\hline $\begin{array}{c}\text { Geotrichum sp. XM05D 26S ribosomal RNA } \\
\text { gene, partial sequence }\end{array}$ & 96 & 99 & EU293419.1 \\
\hline $\begin{array}{l}\text { Geotrichum sp. DTQ-LP20.11 26S ribosomal } \\
\text { RNA gene, partial sequence }\end{array}$ & 97 & 99 & EF025925.1 \\
\hline $\begin{array}{c}\text { Galactomycesgeotrichum 26S ribosomal RNA } \\
\text { gene, partial sequence }\end{array}$ & 97 & 99 & DQ849321.1 \\
\hline $\begin{array}{l}\text { Galactomyces candidum strain Y4 26S ribosomal } \\
\text { RNA gene, partial sequence }\end{array}$ & 96 & 99 & KM391952.1 \\
\hline $\begin{array}{c}\text { Galactomyces geotrichum genomic DNA } \\
\text { containing 28S rRNA gene, strain ABM5136 }\end{array}$ & 96 & 99 & HG532114.1 \\
\hline $\begin{array}{c}\text { Galactomyces geotrichum strain LMA-76 18S } \\
\text { ribosomal RNA gene, internal transcribed spacer } \\
\text { 1, 5.8S ribosomal RNA gene, internal transcribed } \\
\text { spacer 2, and 28S ribosomal RNA gene, complete } \\
\text { sequence }\end{array}$ & 97 & 99 & JF262192.1 \\
\hline $\begin{array}{c}\text { Galactomyces geotrichum strain LMA-75 18S } \\
\text { ribosomal RNA gene, internal transcribed spacer } \\
\text { 1, 5.8S ribosomal RNA gene, internal transcribed } \\
\text { spacer 2, and 28S ribosomal RNA gene, complete } \\
\text { sequence }\end{array}$ & 97 & 99 & JF262191.1 \\
\hline $\begin{array}{l}\text { Galactomycesgeotrichum strain LMA-40 18S } \\
\text { ribosomal RNA gene, internal transcribed spacer } \\
\text { 1, 5.8S ribosomal RNA gene, internal transcribed } \\
\text { spacer 2, and 28S ribosomal RNA gene, complete } \\
\text { sequence }\end{array}$ & 97 & 99 & JF262187.1 \\
\hline $\begin{array}{l}\text { Geotrichum sp. HNC-2 26S ribosomal RNA } \\
\text { gene, partial sequence }\end{array}$ & 96 & 9 & EU753719.1 \\
\hline $\begin{array}{c}\text { Galactomyces candidum strain CBS } 357.86 \text { 26S } \\
\text { ribosomal RNA gene, partial sequence }\end{array}$ & 97 & 99 & JN974274.1 \\
\hline $\begin{array}{c}\text { Galactomyces geotrichum strain LMA-74 18S } \\
\text { ribosomal RNA gene, internal transcribed spacer } \\
\text { 1, 5.8S ribosomal RNA gene, internal transcribed } \\
\text { spacer 2, and 28S ribosomal RNA gene, complete } \\
\text { sequence }\end{array}$ & 97 & 99 & JF262190.1 \\
\hline $\begin{array}{c}\text { Galactomyces geotrichum strain LMA-73 18S } \\
\text { ribosomal RNA gene, internal transcribed spacer } \\
\text { 1, 5.8S ribosomal RNA gene, internal transcribed } \\
\text { spacer 2, and 28S ribosomal RNA gene, complete } \\
\text { sequence }\end{array}$ & 97 & 99 & JF262189.1 \\
\hline $\begin{array}{c}\text { Galactomyces geotrichum strain LMA-15 1 } \\
\text { ribosomal RNA 8S gene, internal transcribed } \\
\text { spacer 1, 5.8S ribosomal RNA gene, internal } \\
\text { transcribed spacer 2, and 28S ribosomal RNA } \\
\text { gene, complete sequence } \\
\end{array}$ & 97 & 99 & JF262180.1 \\
\hline
\end{tabular}




\begin{tabular}{|c|c|c|c|}
\hline $\begin{array}{c}\text { Geotrichum sp. 190 LC-2011 26S ribosomal } \\
\text { RNA gene, partial sequence }\end{array}$ & 97 & 99 & JN417625.1 \\
\hline $\begin{array}{c}\text { Fungal yeast sp. DY85 26S ribosomal RNA gene, } \\
\text { partial sequence }\end{array}$ & 96 & 99 & EU445458.1 \\
\hline $\begin{array}{c}\text { Geotrichum candidum culture-collection } \\
\text { CBS:9194 large subunit ribosomal RNA gene, } \\
\text { partial sequence }\end{array}$ & 97 & 99 & KY107740.1 \\
\hline $\begin{array}{c}\text { Galactomyces sp. HIT-BY2 26S ribosomal RNA } \\
\text { gene, partial sequence }\end{array}$ & 98 & 99 & FJ219590.1 \\
\hline
\end{tabular}

An analysis of phylogenetic kinship constructed using strains of closely related microorganisms showed that the closest to the studied strain was the species Geotrichum candidum, which served as the basis for its deposit under number 977 at the Research Center "Kurchatov Institute" - State Research Institute of Genetics. Strain G. candidum 977 was characterized by large cells and the ability to assimilate the components of the grain processing product. The possibility of using the strain G. candidum 977 for the processing of serum from triticale was evaluated in stages:

- $\quad$ preparation of the substrate by adjusting the $\mathrm{pH}$ and sterilization;

- $\quad$ sowing of the nutrient medium by the producer in an amount of $2-3 \%$ of its mass;

- $\quad$ producer fermentation on a rocking chair at $150 \mathrm{~min}^{-1}$ and a temperature of $28{ }^{\circ} \mathrm{C}$.

The yield of G. candidum 977 biomass depended on the acidity of the medium (Fig. 1). The culture showed viability in the range of $\mathrm{pH}$ from 5.5 to 8.5. During growth strain G. candidum 977 alkalized the medium from $\mathrm{pH} 5.5$ to a final value of 8.5 as indicated by $\mathrm{pH}$ values of the culture fluid.

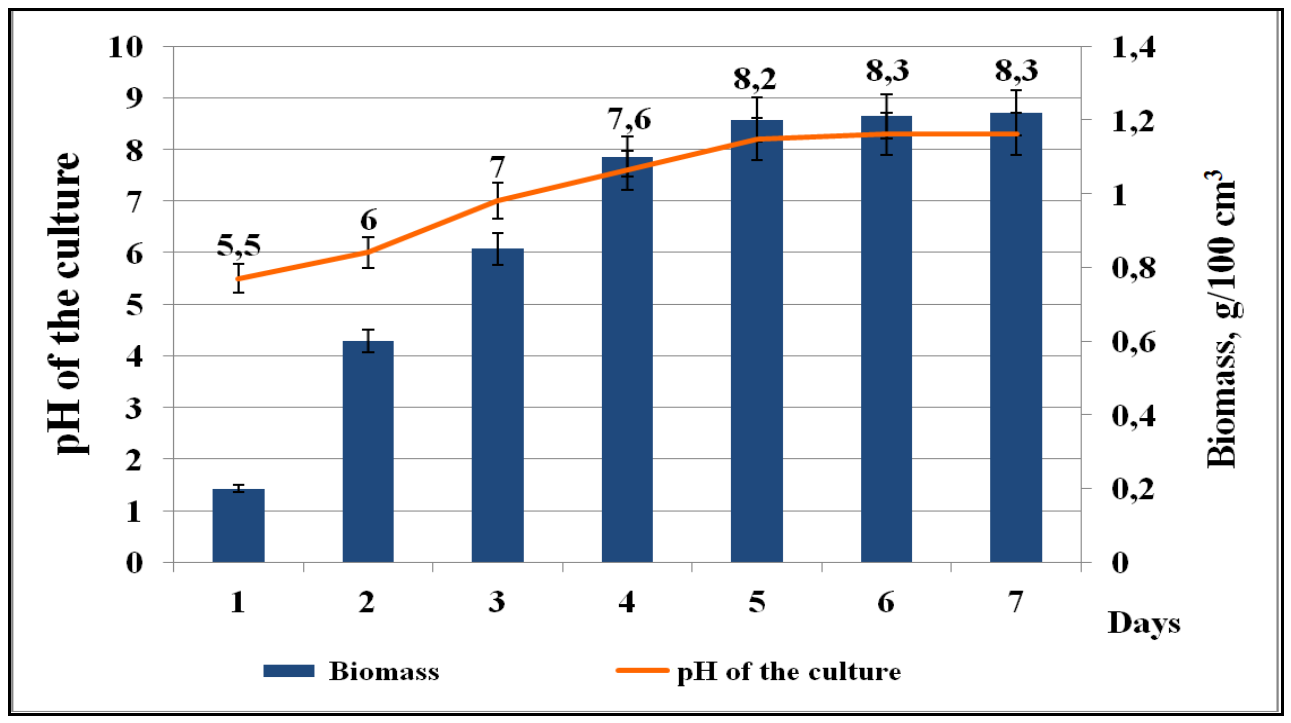

Fig. 1. Change in $\mathrm{pH}$ of the culture fluid during cultivation of the fungus Geotrichum candidum 977.

At a $\mathrm{pH}$ of 5.0 the growth of the fungus was not observed, at $\mathrm{pH}$ 5.5-6.5 it was insignificant, at $\mathrm{pH} 7.5-8.5$ it was maximum, the yield reached $3.0-3.15 \mathrm{~g} / 100 \mathrm{~cm}^{3}$ (Fig. 2). During fermentation at $\mathrm{pH} 7.5$ intense foaming was observed. 


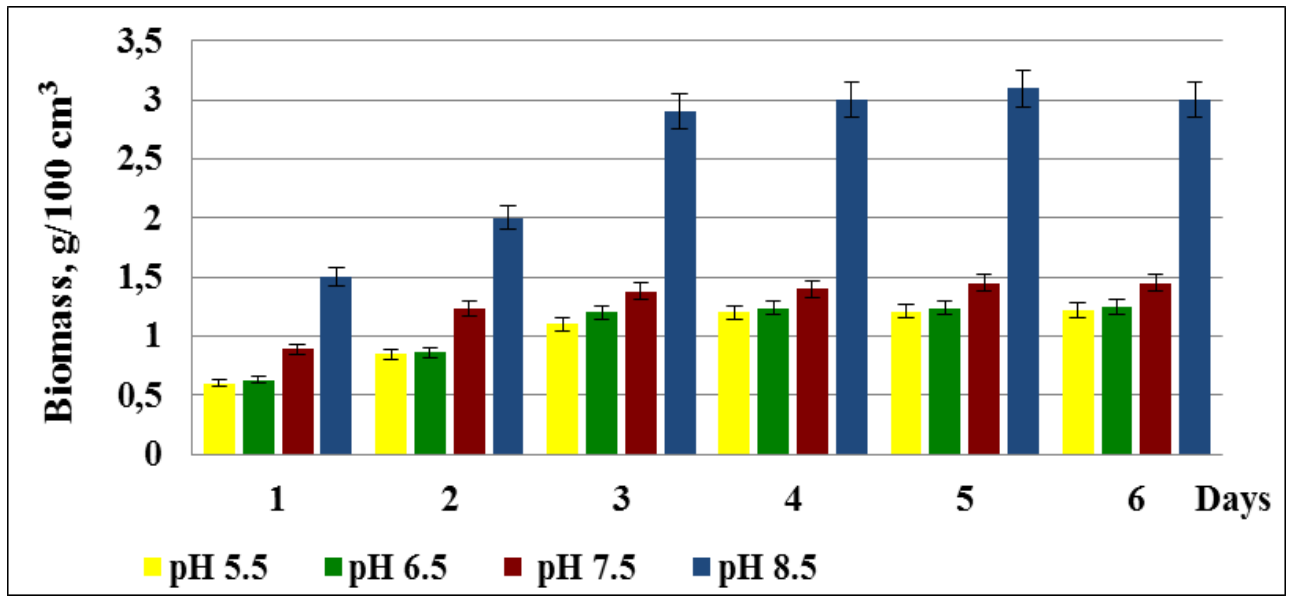

Fig. 2. Dynamics of biomass accumulation of Geotrichum candidum 977 at various $\mathrm{pH}$ values.

As the fungus grew the mass fraction of DS in the culture fluid compared with the nutrient medium decreased 1.16-1.2 times reducing sugars decreased 2.6-2.7 times (Fig. 3). The fungus G. candidum 977 fully absorbed glucose, fructose and maltotriose. Maltotriosis was used by the fungus only at the beginning of growth up to 3 days, in the future its amount remained almost unchanged, and maltose did not assimilate (Fig. 4).

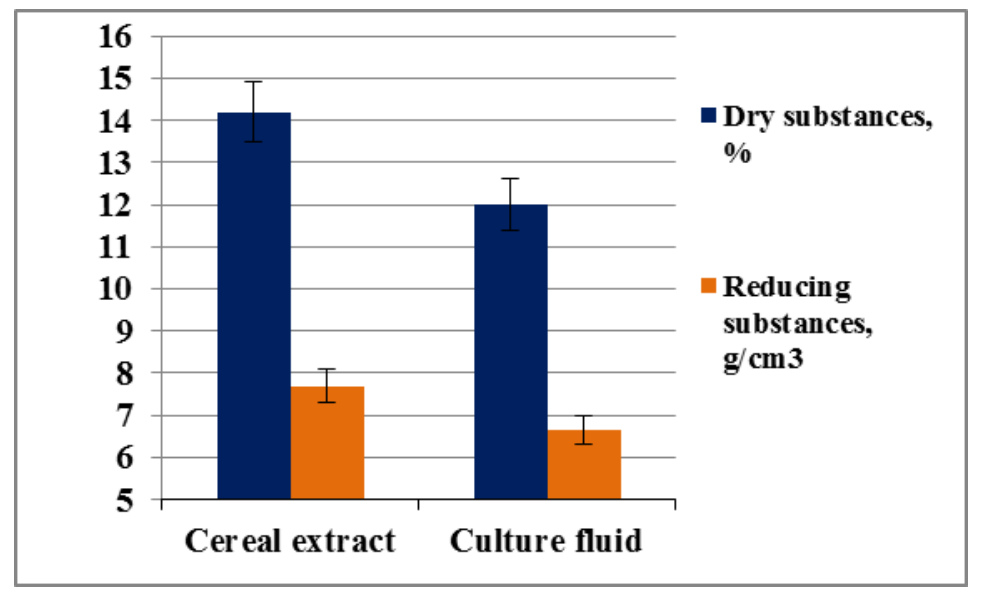

Fig. 3. Change in the nutrient medium mass fraction of dry substances and reducing substances in the fermentation process. 


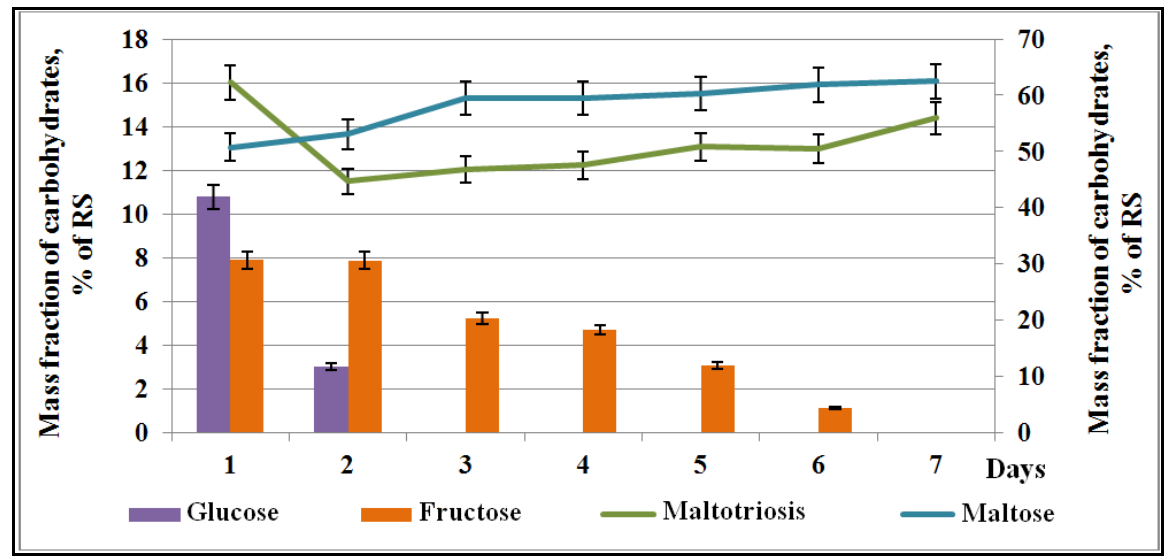

Fig. 4. The dynamics of the absorption of substrate carbohydrates by the fungus.

The culture fluid slightly increased the content of maltose and macromolecular compounds (dextrins). The MVC had the appearance of a friable powder of light cream color with a pleasant odor, neutral taste and a mass fraction of protein of $33.3 \pm 0.3 \%$ of DS. The MVC contained 19 amino acids, glutamic acid, aspartic acid, alanine prevailed among the essential ones, and lysine, leucine, and threonine were among the essential amino acids (Fig. 5).

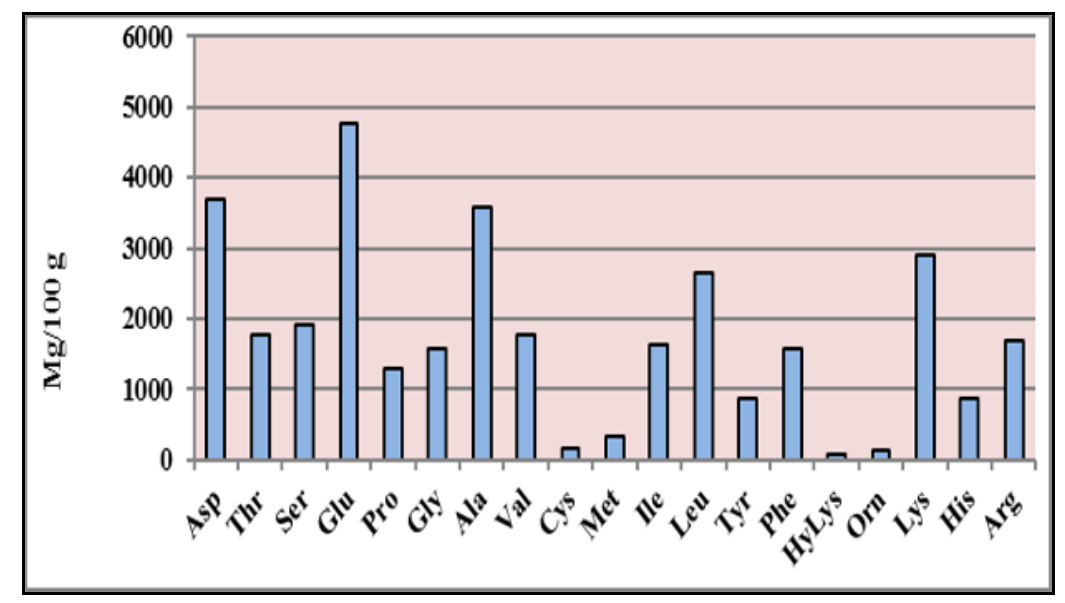

Fig. 5. Amino acid composition of MVC, $\mathrm{mg} / 100 \mathrm{~g}$ of product.

The score of essential amino acids including lysine and threonine, which are deficient in cereals, was higher than $100 \%$ (Table 2 ). The exception was sulfur-containing amino acids (methionine + cystine) for which the rate was $64 \%$.

Table 2. Amino acid score of microbial-vegetable concentrate, $\%$.

\begin{tabular}{|c|c|c|c|c|c|c|}
\hline Thr & Val & Cys+Met & Ile & Leu & Tyr+Phe & Lys \\
\hline 215 & 132 & 64 & 165 & 132 & 182 & 184 \\
\hline
\end{tabular}

In microbiological production cultures with artificially modified genotype are widely used. However, the construction of genetically modified crops is a complex, lengthy, expensive process. Such microorganisms are sometimes distinguished by increased genetic and physiological instability, require a special assessment of biological and environmental 
safety with industrial use a constant selection of active cultures is necessary. Therefore today the search for natural crops for biotechnology does not lose its relevance. The isolated and identified strain of the fungus as G. candidum 977 was characterized by useful technological properties and given the cost of microbiological production the cost of raw materials is about $50 \%$, then the fermentation of the strain of this substrate will be justified. With a positive reaction of the culture of G. candidum 977 on the composition of the medium the serum provided a sufficient yield. At the same time the acidity of the medium with the ability of the culture to alkalize it influenced the amount of biomass. It is possible that an increase in the $\mathrm{pH}$ of the medium was associated with the substitution of amino acids utilized by the fungus when feeding, while for example when cultivating $S$. cerevisiae yeast on medium from watermelon juice on the contrary acidity increased. Active growth at $\mathrm{pH}$ 8.5-10.5 is known for a limited amount of yeast for example for Yarrowia lipolytica. It is assumed that the resistance of $Y$. lipolytica yeast to high $\mathrm{pH}$ values is associated with the presence of two independent systems of metabolite transport through the plasma membrane.

The ability of fungi of the genus Geotrichum to increase the $\mathrm{pH}$ of the substrate and synthesize biomass at $\mathrm{pH} 8.5$ is not described in the literature. It is possible that in this case the transition of carbohydrate nutrition of the strain to nitrogen nutrition was observed with the formation of protein hydrolysis products by G. candidum 977 proteolytic enzymes in particular, basic amino acids and an increased amount of amine nitrogen. Active foaming during cultivation of G. candidum 977 on a nutrient medium at $\mathrm{pH} 7.5$ can be explained by a violation of the phosphorus nutrition of yeast and the transition of calcium phosphorus salts into insoluble foaming tricalcium phosphates.

Analysis of the data we published earlier for serum formed after removal of proteins from secondary products of processing triticale grain into starch showed that with Saccharomyces cerevisiae 121 yeast, the mass fraction of protein in MVC reached $25.2 \pm$ $2.1 \%$ of DS [20], with P. ostreatus 23 fungus $-28.9 \pm 7.2 \%$ of DS [21]. The score of essential amino acids with the exception of sulfur-containing amino acids (51\%) was above $100 \%$. Aspartic acid, glutamic acid, alanine, arginine predominated among the replaced amino acids, and lysine, threonine, valine and leucine predominated from the essential amino acids. In MVC obtained on protein-free serum from triticale with G. candidum 977 fungus the mass fraction of protein is higher than with Saccharomyces cerevisiae 121 yeast and it slightly differed with $P$. ostreatus 23 fungus $(33.3 \pm 0.3 \%$ of DS). The score of sulfur-containing amino acids of MVC remained practically at the same level (64\%) (table 2). The score of deficient essential amino acids of cereals such as lysine, threonine, leucine was $13-24 \%$ higher compared to the MVC synthesized with Saccharomyces cerevisiae 121 yeast. The score of sulfur-containing amino acids was slightly higher (71-72\%), if a consortium of Saccharomyces cerevisiae 121 with the fungus G. candidum 977 was used for serum waters formed after isolation of protein two-component composites from triticale extract and pea flour, proteins in which were correlated as 1:3 and 1:5, respectively. The biosynthetic process of transformation of the extract and from pea flour ensured the production of MVC with a mass fraction of proteins, in \% of DS: protein - 55.8-75.1, carbohydrates - 18.9-32.83, fat - 3.56-13.56, ash - 2,05-8.27 [23]. The serum formed after the isolation of proteins from the composition of the triticale extract and pea flour was the most effective for the nutrient medium of microbiological synthesis. The proposed disposal method reduced the consumption of water and additional mineral or organic raw materials for the preparation of culture media. 


\section{Conclusions}

The possibility of using a new strain of G. candidum 977 for bioconversion of serum triticale remaining after the removal of proteins from soaking waters generated during the production of starch is shown. During growth the fungus G. candidum 977 completely absorbed glucose, fructose and at the beginning of growth, maltotriose, the fungus did not assimilate maltose. The ability of the fungus to alkalize the substrate from an initial $\mathrm{pH}$ of 5.5 to a final $\mathrm{pH}$ of 8.5 with an increase in biomass was found. The MVC contained $33.3 \pm$ $0.5 \%$ protein of DS. The score of essential amino acids exceeded $100 \%$, with the exception of sulfur-containing amino acids (64-72\%). The ability of the strain to ensure the transformation of the component composition of secondary products of grain processing (protein-free whey) into technological quality indicators of MVC has been proved, further study of which will show the directions of their use. To achieve a higher protein content and high-quality amino acid composition of $\mathrm{MVC}$, the serum formed after removing proteins from a composition consisting of triticale extract and pea meal was the most effective as a nutrient medium for G. candidum 977 fungus. The MVC are intended for use in feed production as a protein-carbohydrate supplement, taking into account the results of safety and digestibility.

\section{References}

1. Sartor M, Kaschek M and Mavrov V 2008 Desalination 224 172-177 DOI: 10.1016/j.desal.2007.04.086

2. O'Donnell C, Brijesh K Tiwari, Cullen P J, Rip G and Wiley R J \& Sons 2012 Ozone in Food Processing 312 ISBN 1118307437, 9781118307434

3. D'Souza N M and Mawson A J 2005 Critical Reviews in Food Science and Nutrition 45 125-134 DOI: 10.1080/10408690490911783

4. Kulnev V V 2017 Ecology and Industry of Russia 21(3) 16-20 DOI: 10.18412/18160395-2017-3 [In Russ.]

5. Olaleye O N, Omotayo M A, Abdus S R B and Olanlege Abdul-Lateef O 2015 Journal of Microbiology Research 5(6) 169-174 DOI:10.5923/j.microbiology

6. Sibtain A, Ghulam M, Muhammad A and Muhammad I R 2017 BioMed Research International 1-9 DOI: 10.1155/2017/6232793

7. Shahzad M A and Rajoka M I 2011 International Journal of Bioscience, Biochemistry and Bioinformatics 1 137-141 DOI: 10.7763 / ijbbb.2011.v1.25

8. Zhang Z Y, Jin B, Bai Z H and Wang X Y 2008 Bioresource Technology 99(9) 38713876 DOI: $10.1016 /$ j.biortech.2006.10.047

9. Kurcz A, Blazejak S, Kot A M, Bzducha-Wrobel A and Kieliszek M 2018 Waste and biomass valorization 9 57-64 DOI: 10.1007/s12649-016-9782-z

10. Munawar R A, Irfan M, Nadeem M, Syed Q A and Siddique Z H 2010 Pakistan Journal of Science 62 1-5 ID: 85593341

11. Patsios S I, Dedousi A, Sossidou E N and Zdragas A 2020 Sustainability 12 Article Number: 1398 DOI: 10.3390/su12041398

12. Hanim K, Rahman A, Yusof S J H M and Zakaria Z 2016 Tropical Agricultural science 39(1) 29-39

13. Boutrou R and Gueguen M 2005 International Journal Food microbiology 102 1-20 DOI: 10.1016/j.ijfoodmicro.2004.12.028

14. Boutrou R, Kerriou L and Gassi J Y 2006 International Dairy Journal 16(7) 775-783 
DOI: $10.1016 /$ j.idairyj.2005.07.007

15. Maldonado R R, Burkert J F M, Mazutti M A, Maugeri F and Rodrigues M I 2012 Biocatalysis and Agricultural Biotechnology 1 147-151 DOI: 10.1016/j.bcab.2012.01.003

16. Coman G, Leuștean I, Georgescu L and Bahrim G 2012 BioResources 7(4) 5290-5303

17. Ladevèze S, Haon M, Villares A, Cathala B, Grisel S, Herpoël-Gimbert I, Henrissat B and Jean-Guy Berrin 2017 Biotechnology for Biofuels 10215 DOI: 10.1186/s13068017-0903-0

18. Cherkasov V D and Ushkina V V 2016 Ural Scientific Herald 6(1) 168-172 [In Russ.]

19. Ziganshin A M, Gerlach R, Naumenko E A and Naumova R P 2010 Microbiology 79(2) 178-183 DOI: $10.1134 /$ S0026261710020086

20. Andreev N R, Kolpakova V V, Kravchenko I K et al. 2017 South of Russia: ecology. Development 4 90-104 DOI: 10.18470/1992-1098-2017-4-90-1 [In Russ.]

21. Lukin N D, Ulanova R V, Kravchenko I K, Kolpakova V V and Goldstein V G 2018 Chemistry of plant raw materials 4 225-234 DOI: 10.14258 / jcprm.2018043993 [In Russ.]

22. Naumova E S, Serpova E V and Naumov G I 2007 Biochemistry (Moscow) 72(12) 1356-1662 DOI: $10.1134 /$ S0006297907120097

23. Kolpakova V V, Ulanova R V, Kulikov D S et al. 2019 Food Processing: Techniques and Technology 2(49) 301-311 DOI: 10.21603/2074-9414-2019-2-301-311 [In Russ.]Type the title of your paper here 